\title{
ФУНКЦІОНАЛЬНИЙ ПІДХД ЩОДО СТАТУСУ УЧАСНИКІВ КРИМІНАЛЬНОГО ПРОЦЕСУ
}

\author{
КОРЕЦЬКИЙ Олег Павлович - начальник відділу Державного бюро \\ розслідування
}

УДК 343.125

DOI 10.32782/LAW.2020.2.11

Статья рассматривает элементьи общих и специальных теорий уголовного процесса. Процессуальные положения системы уголовного прочесса определяется на основе въполнения функиий участников, которье имеют процессуальньй статус. Права участника предусматривает въгполнение обязанностей на основе гарантий прав и законнъгх интересов при проведении прочессуальньх, следственных розъскных и судебньих действий. Действующий УПК Украинъ установил новых участников уголовного судопроизводства сторонъ обвинения, однако прочессуальный статус их до кониа не урегулирован, что възывает теоретические проблемь на практике. Рассматривается процессуальный статус и данъ практические предложения механизма регулирования.

Ключевъие слова: статус, гарантии, механизм, бункиия, дознаватель, руководитель органа дознания, следователь, прокурор, судья, участник процесса.

Актуальність статті

Процесуальний статус учасників кримінального провадження є однією $з$ найважливіших складових його системи, яка забезпечує швидкість, неупередженість, справедливість і ефективність кримінального провадження. Системний підхід дозволяе розібратися у співвідношенні прав і свобод, а також їх взаємовідносини між учасниками процесу. Системний підхід щодо учасників кримінального провадження, які беруть участь у доказуванні необхідно застосовува- ти у кримінальному провадженні на підставі засад, визначених прав, обов'язків та функціонального підходу.

Теоретичні конструкції учасників кримінального процесу були предметом розгляду багатьох вчених. Усі вони відзначали структурну побудову на підставі функціонального підходу, процесуального статусу учасників та забезпечення гарантій прав, свобод та інтересів під час кримінального провадження. Перша конструкція передбачає функціональний підхід до участі сторін, учасників процесу у встановленні обставин кримінального правопорушення, вини підозрюваного, обвинуваченого на стадіях процесу. Основна структура функціонального розподілу учасників процесу встановлена щодо сторони обвинувачення та захисту.

\section{Мета статті}

Визначити процесуальний статус учасників кримінального провадження на підставі виконання процесуальних функцій. Розглянути теоретичні положення функціонального забезпечення кримінального процесу та визначити статус учасників, який встановлений гарантіями процесу. Розглянути нових учасників сторони обвинувачення, що визначені у чинному КПК України. Надати процесуальний механізм виконання прав, обов'язків учасниками процесу.

\section{Теоретичні положення}

Процесуальний розгляд статусу учасників кримінального процесу необхідно визна- 


\section{Кримінальне право, кримінальний процес та криміналістика}

чати на підставі їх функцій. Перші положення функціонального підходу були визначені Ю.П. Аленіним, О.В. Бауліним, Н.С. Карповим, В.Д. Берназ, В.І. Галаган, І.В. Басіста, Ж.В. Удовенко, В.В. Назаровим, С.В. Слінько, І.Я. Фойницький, П.С. Єлькінд та ін. [2; 3; 4, с. 35; 5; 9;11;14;15].

I.В. Басіста, В.І. Галаган, Ю.М. Грошевой, І.В. Гловюк, О.В. Капліна та ін. вважали, що кримінальні процесуальні функції - це напрямок, в окремих випадках вид кримінальної процесуальної діяльності.У такому випадку функції охоплюються метою встановлення обставин кримінального правопорушення та участі учасників процесу під час встановлення вини підозрюваного, обвинуваченого [5; 6; 7].

С.А. Альперт, розкриваючи зміст процесуальних функцій вважав, що процесуальні діï учасника кримінального провадження повинні бути визначені його процесуальною позицією, або сторони обвинувачення, або захисту, або участь у встановленні обставин кримінального правопорушення [1, с.10]

Наука кримінального процесу одержала розвиток концепції трьох основних процесуальних функцій - обвинувачення або кримінального переслідування, захисту, вирішення матеріалів кримінального провадження. Однак, ця концепція в період іï становлення залишала поза розглядом кілька істотних теоретичних та практичних питань кримінального процесу. 3 одного боку, до кінця не визначено, які функції здійснюються на досудових стадіях процесу. 3 іншого, не зрозуміло, яке значення мають для проведення досудового розслідування рішення дізнавача, слідчого, прокурора, слідчого судді. Які функції повинен виконувати цивільний позивач, відповідач, заявник, свідок, експерт, спеціаліст та ін.

Першу концепцію підтримав ряд учених, які пропонували доповнити кримінальний процес новими функціями.

Аналіз теоретичних положень функціонального призначення у кримінальному процесі свідчить, що ні один 3 учених не вийшов за межі загальноприйнятої доктрини, що кримінально процесуальні функції - це напрямки діяльності учасників процесу, які здійснюються з метою виконання поставлених завдань кримінального провадження. Основні доктринальні дослідження функцій проводяться на підставі їх класифікації. Можна визначити теоретичні підходи, а саме мінімалістський та максималістський. Одні вчені визначають перший підхід та обгрунтовують свої погляди щодо основних трьох функцій кримінального процесу. Інші вказують на основні та додаткові функції.

M.С. Строгович один з перших визначив три основні функції процесу, зокрема функцію кримінального обвинувачення, функцію кримінального захисту та функцію вирішення сутності кримінального провадження [12].

Другий концептуальний підхід був запропонований опонентами, які вважали, що необхідно визначити нові функції, що виходять за рамки правової дефініції цього поняття. Їх висловлювання можна визначити таким чином, що кримінальні процесуальні функції повинні охоплювати, з одного боку, призначення норм права для встановлення обставин кримінального правопорушення. 3 іншого, вони повинні діяти у напрямку впливу на правові відносини між учасниками кримінального провадження. Розкриваючи елементи функції, необхідно мати на увазі структурне призначення права 3 його напрямками.

Р.Д. Рахунов відмовився від концепції розподілу кримінального процесу на три функції. Він підкреслював, що функція розслідування - це не функція обвинувачення, більше того ці функції не збігаються між собою. Розглядаючи функціональне визначення сторін процесу, було запропоновано шість функцій, які виконують учасники кримінального провадження, зокрема розслідування, обвинувачення, захист, вирішення матеріалів кримінального провадження, підтримання цивільного позову, захист від позову. Усі визначені функції були розподілені між учасниками кримінального процесу. Функціональний підхід був встановлений на підставі розподілу кримінальних процесуальних повноважень між сторонами, учасниками процесу на підставі їх правового статусу. Так функція розслідування виконується дізнавачем, слідчим, прокурором. Функція захисту здійснюється підозрю- 
ваним, обвинуваченим, захисником. Особливе значення мають функції підтримання цивільного позову та захисту від нього [10].

O.M. Аарін вважав, що сторонам кримінального процесу властива поліфункціональна побудова функцій. Він вважав, що суперечки між функціями обвинувачення та захисту немає тому, що у кримінальному процесі існує функція обвинувачення, та їй протистоїть функція захисту. «Проти кого спрямовані зусилля обвинуваченого і захисника, чому протистоїть функція захисту, якщо вважати, що під час досудового розслідування немає функції обвинувачення?» [8.c. 45]

Ф.Н. Фаткуллін запропонував розділити функцію обвинувачення та захисту та встановити єдину функцію, яка передбачає охорону прав, свобод та інтересів учасників процесу [13, с. 40]. Ця пропозиція викликає зауваження. Кримінальний процесуальний закон надає особливе значення захисту прав, свобод та законних інтересів учасників кримінального провадження. Захист не може існувати у відриві від обвинувачення, а також від інших форм кримінального процесу.

Третій концептуальний підхід визначає процесуальні функції, як розподіл функцій на загальні та приватні функції процесу.

Необхідно зауважити, що декілька вчених розходяться як у формулюванні, так i у кількості функцій. До трьох основних функцій додається: функція розслідування кримінального провадження; підтримка цивільного позову та захист від нього; прокурорський нагляд у формі процесуального керівництва; судовий розгляд кримінальної справи; нагляд суду вищої інстанції за розглядом кримінального провадження судом першої інстанції. Були пропозиції, визначення процесуальних функцій, а саме у протидії злочинності; забезпечення відшкодування матеріальних збитків, які наступили за результатом вчинення злочину та ін.

\section{Виклад загального матеріалу}

Неможливо сказати, яка функція у кримінальному процесі з'явилася першою, а яка другою. Функція встановлення обставин кримінального правопорушення та дове- дення вини підозрюваного, обвинуваченого зобов’язує органи кримінальної юстиції почати кримінальне провадження та встановити класифікацію вини підозрюваного у вчиненні кримінального правопорушення. Таким чином, органи кримінальної юстиції на підставі функції починають кримінальне провадження, а не навпаки.

КПК України не визначає функціонального розподілу учасників кримінального провадження. Основа теоретичних поглядів була встановлена у теоретичному розподілу. Сторона обвинувачення включає до себе слідчого, керівника органу досудового розслідування, дізнавача, керівника органу дізнання, прокурора, оперативні підрозділи та його співробітників, які виконують доручення слідчого під час досудового розслідування. Окремий статус має потерпілий як сторона обвинувачення. Він має повноваження підтримувати кримінальний позов під час судового розгляду, якщо прокурор, як публічний обвинувач, відмовиться від обвинувачення. Також включені законний представник потерпілого, цивільний позивач та його представник.

Сторону захисту представляє підозрюваний, обвинувачуваний, їх законні представники, адвокат (захисник), цивільний відповідач, його законний представник.

Інші учасники кримінального процесу закон підрозділяе на учасників, які допомагають виконанню завдань кримінального провадження (спеціаліст, експерт) та учасники, які не мають процесуальних інтересів під час досудового розслідування та судового розгляду кримінального провадження (свідок, перекладач, понятий).

Слідчий суддя, колегіальний суд, суддя виконують функцію вирішення матеріалів кримінальної справи, встановлюють вину підозрюваного на стадії досудового розслідування та судового розгляду, складають ухвалу, проголошують вирок. На перший погляд, три визначені функції є основними, вони перебувають у нерозривній єдності, кожна 3 них вважає застосування двох інших. Кожна процесуальна функція обвинувачення та захисту виконують функцію 


\section{Кримінальне право, кримінальний процес та криміналістика}

встановлення обставин кримінального правопорушення та доведення вини.

Пропонуємо визначити функції кримінального провадження. Перша функція - кримінальне обвинувачення. Вона підрозділяється на підфункції: встановлення особи яка вчинила кримінальне правопорушення; підтримка публічного обвинувачення державними органами прокуратури, за забезпечення прокурорського нагляду у формі процесуального керівництва; складання, оголошення повідомлення про підозру, за даним обвинуваченням підозрюваний притягується до кримінальної відповідальності. Функція кримінального захисту, включає до себе підфункції: захист прав учасників кримінального провадження; захист підозрюваного, обвинуваченого від обвинувачення. Функція - правосуддя. Вона повинна діяти на стадії досудового провадження, а саме забезпечити судовий контроль з боку слідчого судді, а також проведення судового розгляду кримінальної справи, ухвалення та проголошення вироку.

На підставі функціонального розподілу сторін, учасників кримінального процесу необхідно визначити процесуальний статус. У теорії кримінального процесу немає однозначної думки щодо визначення правового статусу сторін, учасників процесу. Класифікація також має декілька видів, виходячи 3 форми процесуальної діяльності. Чинне законодавство встановило значну кількість учасників процесу.

Теорія права визначає конституційний правовий, загальний, спеціальний, індивідуальний статус. Конституційний правовий статус визначений у Конституції України та включає право на життя, на повагу до його гідності, на свободу та особисту недоторканність та ін. Загальний статус включає до себе права, обов'язки та інтереси громадянина, якими він користується в суспільстві. Спеціальний та індивідуальний статус у кримінальному процесі встановлений на підставі диспозиції статті КПК України. Загальною основою для правового статусу є конституційний статус. Цей інститут складається із загальних положень користування прав, обов'язків, гарантій.
Необхідно визначити, що в теорії кримінального процесу не має однозначної думки визначення правового статусу учасників кримінального провадження та їх класифікації. Інститут правового статусу встановив положення, які визначають розмежування функцій кримінального обвинувачення між учасниками; обвинувачення, захисту та правосуддя; встановлення класифікації учасників, які здійснюють кримінальне провадження або берут у ньому участь; аналізують його систему складових у взаємозв'язку, взаємної обумовленості та взаємозалежності.

Закон визначає процесуальний статус сторони обвинувачення. Згідно зі ст. 36 КПК України прокурор здійснює прокурорський нагляд за додержанням законів під час проведення досудового розслідування у формі процесуального керівництва досудовим розслідуванням. Процесуальний статус слідчого встановлений на підставі повноважень починати та проводити досудове розслідування.

Ст. 40-1 КПК України розкриває процесуальний статус дізнавача, який має процесуальні повноваження щодо розслідування кримінальних проступків. Закон надав дізнавачу під час досудового розслідування статус слідчого. Однак, його повноваження ст. 214 КПК України розширила, він має право відбирати пояснення; призначати проведення медичного освідування; отримувати висновок спеціаліста, який встановлений на підставі технічних засобів; вилучати знаряддя і засоби вчинення кримінального проступку, а саме речі і документи, що є безпосереднім предметом кримінального проступку, або які виявлені під час затримання особи; особисто проводити огляд.

Теоретична неузгодженість процесуальних прав та обов'язків дізнавача викликає занепокоєння. По-перше, теоретичні положення КПК України вказують, що слідчий, дізнавач повинні починати досудове розслідування тільки після внесення відомостей про вчинене кримінальне правопорушення до єдиного реєстру досудового розслідування. Тому, як пояснення, можна визначати доказом у кримінальному процесі, якщо вони отримані до початку кримінального розслідування. Так саме не можна 
призначати освідування особи, без їі заяви, яка повинна бути зареєстрована. Тобто дізнавач за чинним КПК України діє поза межами кримінального процесу. Уцьому разі це порушення не тільки КПК України, а порушення засад, гарантій учасників кримінального процесу. По-друге, дізнавач має право затримати особу та особисто провести огляд місяця події, предметів, речей, документів та ін. Однак, ст. ст. 42 - 45 КПК України вказує, що у разі затримання особи, що підозрюється у вчиненні кримінального правопорушення повинен бути присутній адвокат, захисник. У цьому разі статус підозрюваного є дуже вузьким та не відповідає чинному законодавству. По-третє, дізнавач отримує результати проведення оперативно розшукових заходів та висновок спеціаліста про застосування технічних засобів. Незрозумілим постає питання участі слідчого судді, який повинен надати ухвалу на проведення негласних слідчих (розшукових) дій. У цьому разі порушується не тільки закон, а також ставиться питання щодо виконання засад, гарантій прав учасників процесу. Якщо всі підстави для оголошення повідомлення про підозру будуть вичерпані, а доказів вини щодо особи, яка підозрюється у вчинені кримінального проступку не буде встановлено, а дізнавач проводив ці дії, то він повинен бути притягнутий до юридичної відповідальності.

Особливої тривоги викликає процесуальні дії дізнавача, який має право починати розслідування кримінального проступку, але до кінця склад кримінального правопорушення не встановлено. Тобто дізнавач починає розслідування щодо тяжкого злочину, але отримує пояснення, проводить фіксацію технічними засобами фактичних даних вчинення кримінального правопорушення, проводить огляд, медичне освідування, і всі процесуальні дії проводяться відносно підозрюваного без адвоката, захисника. Проводиться фіксація за допомогою пояснення. Таким чином, підозрюваного вводять в обману, він не отримує свого процесуального статусу, який встановлено КПК України, не має можливості захисту. Після проведення дізнання дізнавач передає матеріали кримінального провадження до прокурора, який надсилає їх до слідчого. Тільки після отримання слідчим матеріалів кримінального провадження статус підозрюваного може бути визнаним, однак непроцесуальні фактичні дані, які надані дізнавачем, слідчий має право визнати як докази. У цьому разі суддя, колегіальний суд пов'язані порушеннями кримінального процесу та не мають процесуального виходу. Суддя повинен розглядати фактичні дані, що отримав дізнавач, та надати їм процесуальну оцінку під час ухвалення та проголошення вироку.

Окреме місце в класифікації учасників кримінального провадження займає слідчий суддя, суддя, колегіальний суд, виходячи $з$ функціонального призначення правосуддя. Як гілка влади, суддя не може бути пов'язаний фактичними даними досудового розслідування. Суд встановлює судові докази під час судового розгляду на підставі змагальності сторін процесу.

\section{Висновок}

Процесуальний статус учасників кримінального провадження повинен бути встановлений на підставі їх функціональної участі у кримінальному провадженні. Кожний учасник процесу повинен бути забезпечений правами та обов'язками, порушення яких не допустимо під час досудового розслідування стороною обвинувачення.

\section{入ітература}

1. Альперт С.А. Кримінально-процесуальні функції: поняття, система, суб'єкти. / С.А. Альперт //-Х.: Основа. 1995 -120с.

2. Аленин Ю. П. Уголовнопроцессуальный кодекс Украины Науч. практ. комментарий / Ю. П. Аленин. Одеська нац. юрид. академія. Харків. Одисей. 2003. - 959 с.

3. Баулін О.В. Процесуальна самостійність і незалежність слідчого та їх правові гарантії. монографія. /О.В.Баулін, Н.С. Карпов// -К.: Нац. акад. внутр. справ України. 2001. -232c.

4. Берназ В.Д. Алгоритм деятельности следователя на начальном этапе досудеб- 


\section{Кримінальне право, кримінальний процес та криміналістика}

ного расследования по УПК Украины /В.Д. Берназ/ Ірпень - 2013. - № 2, - С. 35-41.

5. Галаган В. I. Кримінальний процес України : навч. посіб. / Басиста I. В., Галаган В. І., Удовенко Ж. В. - К. : Центр учбової ᄉ-ри, 2010. - 352 с.

6. Гловюк I.В. Кримінально процесуальні функції: теорія, методологія та практика реалізації на основі положень Кримінального процесуального кодексу України /І.В. Гловюк - Одеса: Юридична література. 2015. - 712c.

7. Капліна О.В. Кримінальний процес України: підручник / О.В. Капліна,Ю.М. Грошевой, О.В. Шило. - Х. Юрид. університет. 2013. - 820с.

8. Аарин А.М. Расследование по уголовному делу: процессуальные функции. /А.М. Аарин// -М.: Юрид. лит. 1986. - 260с.

9. Назаров В.В. Конституційні права людини та їх обмеження у кримінальному процесі України. /В.В. Назаров// -Х. Золота миля. 2009.- 400с.

10. Рахунов Р.Д. Участники уголовно процессуальной деятельности по советскому праву. /Р.Д. Рахунов// - М.: Юрид. лит. 1961. - 210c.

11. Слінько С. В. Теорія та практика реформування досудового розслідування /С. В. Слінько. - Харків : Владимиров, 2011. - $280 \mathrm{c}$.

12. Строгович М.С. Курс советского уголовного процесса. /M.С. Строгович -М.: Юриздат НКЮ СССР. 1958. - 440с.

13. Фаткуллин Ф.Н. Общие проблемы процессуального доказывания. /Ф.Н. Фаткуллин // -Казань.: Казанский гос. ун-т. 1973. $-140 \mathrm{c}$.

14. Фойницкий И.Я. Курс уголовного судопроизводства:учебник /И.Я. Фойницкий т. 1. -СПб.: Наука. 1996.- 586с.

15. Әлькинд П.С. Сущность советского уголовно - процессуального права./П.С. Әлькинд// -ᄉ.: АГУ. 1968. - 195с.

\section{Reference}

1. Al'pert S.A. Kriminal'no-procesual'ni funkciï: ponjattja, sistema, sub'ekti. /S.A. Al'pert //-H.: Osnova. 1995 -120s.

2. Alenin Ju. P. Ugolovno-processual'nyj kodeks Ukrainy Nauch. prakt. kommentarij /
Ju. P. Alenin. - Odes'ka nac. jurid. akademija. Harkiv. Odisej. 2003. - 959 s.

3. Baulin O.V. Procesual'na samostijnist' i nezalezhnist'

slidchogo ta ih pravovi garantiï. monografija. /O.V.Baulin, N.S. Karpov// -K.: Nac. akad. vnutr. sprav Ukraïni. 2001. -232s.

4. Bernaz V.D. Algoritm dejatel'nosti sledovatelja na nachal'nom jetape dosudebnogo rassledovanija po UPK Ukrainy / V.D. Bernaz/ Irpen' - 2013. - № 2, - S. 35-41.

5. Galagan V. I. Kriminal'nij proces Ukraïni : navch. posib. / Basista I. V., Galagan V. I., Udovenko Zh. V. - K. : Centr uchbovoï l-ri, 2010. - 352 s.

6. Glovjuk I.V. Kriminal'no procesual'ni funkciï: teorija, metodologija ta praktika realizaciï na osnovi polozhen' Kriminal'nogo procesual'nogo kodeksu Ukraïni/I.V. Glovjuk - Odesa: Juridichna literatura. 2015. - 712s.

7. Kaplina O.V. Kriminal'nij proces Ukraïni: pidruchnik / O.V. Kaplina, Ju.M. Groshevoj, O.V. Shilo. - H. Jurid. universitet. 2013. - 820s.

8. Larin A.M. Rassledovanie po ugolovnomu delu: processual'nye funkcii. /A.M. Larin// -M.: Jurid. lit. 1986. - 260s.

9. Nazarov V.V. Konstitucijni prava ljudini ta ïh obmezhennja u kriminal'nomu procesi Ukraïni. /V.V. Nazarov// -H. Zolota milja. 2009.400 s.

10. Rahunov R.D. Uchastniki ugolovno - processual'noj dejatel'nosti po sovetskomu pravu. /R.D. Rahunov// - M.: Jurid. lit. 1961. -210 s.

11. Slin'ko S. V. Teorija ta praktika reformuvannja dosudovogo rozsliduvannja /S. V. Slin'ko. - Harkiv : Vladimirov, 2011. - 280 s.

12. Strogovich M.S. Kurs sovetskogo ugolovnogo processa. /M.S. Strogovich -M.: Jurizdat NKJu SSSR. 1958. - 440s.

13. Fatkullin F.N. Obshhie problemy processual'nogo dokazyvanija. /F.N. Fatkullin // -Kazan'.: Kazanskij gos. un-t. 1973. - 140s.

14. Fojnickij I.Ja. Kurs ugolovnogo sudoproizvodstva:uchebnik/I.Ja. Fojnickij t. 1. -SPb.: Nauka. 1996.- 586s.

15. Jel'kind P.S. Sushhnost' sovetskogo ugolovno - processual'nogo prava./P.S. Jel'kind// -L.: LGU. 1968. - 195s. 


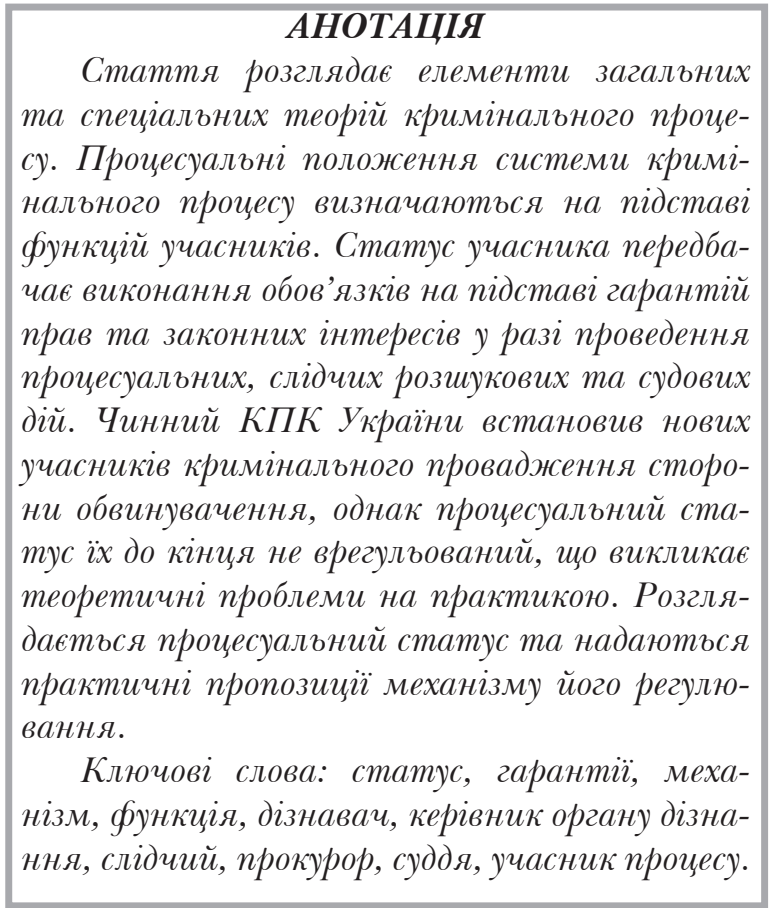

\section{FUNCTIONAL APPROACH REGARDING THE STATUS OF THE PARTICIPANTS IN THE GRIMINAL PROCESS}

The article considers elements of general and special theories of criminal procedure. Procedural provisions of the criminal procedure system are determined on the basis of the functions of the participants. The status of a participant presupposes the performance of duties on the basis of guarantees of rights and legitimate interests in the event of procedural, investigative, investigative and judicial actions. The current CPC of Ukraine has established new participants in the criminal proceedings of the prosecution, but their procedural status has not been fully resolved, which causes theoretical problems in practice. Procedural status is considered and practical proposals of the mechanism of its regulation are given.

Key words: status, guarantees, mechanism, function, coroner, head of the body of inquiry, investigator, prosecutor, judge, participant in the process. 